\title{
Marta Sordyl
}

Uniwersytet Ekonomiczny w Krakowie

e-mail: sordylm@uek.krakow.pl

\section{RYZYKO SEKULARNEJ STAGNACJI W KRAJACH UNII EUROPEJSKIEJ}

\section{RISK OF SECULAR STAGNATION IN THE EU}

DOI: $10.15611 /$ pn.2018.529.28

JEL Classification: E32, J11, E24, E61

Streszczenie: Przedłużająca się recesja po globalnym kryzysie finansowym spowodowała odnowienie zainteresowania hipotezą sekularnej („wieczystej”) stagnacji, zaproponowaną przez Hansena [1939] jako wyjaśnienie trudnej sytuacji gospodarki Stanów Zjednoczonych w latach 30. XX wieku. Doświadczenia krajów rozwiniętych w ciągu ostatnich dziesięciu lat sugerują możliwość istnienia strukturalnych zagrożeń dla trwałego wzrostu. Celem niniejszego opracowania jest identyfikacja czynników, które mogą osłabiać wzrost w krajach UE, a także wskazanie narzędzi zapobiegających stagnacji. W części pierwszej omówiono główne źródła spowolnienia wzrostu (najważniejsze z nich to niski przyrost naturalny, spadek inwestycji, niepewność w gospodarce światowej, rosnące nierówności dochodu, ograniczenia skuteczności tradycyjnej polityki popytowej). W części drugiej przedstawione zostały propozycje reform wspierających stabilny wzrost gospodarczy w krajach UE.

Słowa kluczowe: sekularna stagnacja, zmiany demograficzne, polityka ekonomiczna.

Summary: Long-lasting recession after the global financial crisis led to renewed interest in the secular stagnation hypothesis, proposed by Hansen [1939] to explain economic difficulties of the US economy in the 1930s. Recent experiences of developed countries suggest the possibility of some structural problems that might undermine stable growth. The purpose of the article is to indentify factors negatively affecting growth in EU countries and point out some counter-measures. The first part presents the main causes of lower growth (the main being low population growth, lower investment, uncertainty in the global economy, rising income inequalities, limited effectiveness of traditional demand policies). The second part describes some reform proposals for stable long-term growth.

Keywords: secular stagnation, demographic transition, economic policy. 


\section{Wstęp}

W powszechnym przekonaniu zdrową gospodarkę charakteryzuje trwały, stabilny wzrost gospodarczy; Gordon [2012, s. 1] kwestionuje jednak założenie, że „wzrost gospodarczy jest ciągłym procesem, który będzie trwać wiecznie. Wzrost praktycznie nie istniał przed 1750 r. i nie ma żadnej gwarancji, że utrzyma się w nieskończoność”. Sceptycyzm ten zdaje się potwierdzać historia ostatnich kilku lat w krajach rozwiniętych, zwłaszcza w USA i strefie euro - przedłużająca się recesja po globalnym kryzysie finansowym doprowadziła do odnowienia zainteresowania hipotezą sekularnej (,wieczystej”) stagnacji [Hansen 1939], czyli trwałego spadku tempa wzrostu gospodarczego w porównaniu z okresem przed kryzysem. Mówiąc ogólnie, osłabienie wzrostu może wynikać $\mathrm{z}$ wolniejszego przyrostu potencjału produkcyjnego lub z niedoboru popytu. W tym drugim przypadku przyczyną mogą być niekorzystne oczekiwania, wysokie zadłużenie publiczne i/lub prywatne, a także rosnące nierówności ekonomiczne, które zmniejszają popyt konsumpcyjny; wszystkie wymienione powodują wzrost skłonności do oszczędzania, nawet przy bardzo niskich stopach procentowych. $Z$ kolei czynniki podażowe obejmują wolniejszy przyrost siły roboczej, mniejsze nakłady na kapitał rzeczowy i ludzki oraz niższe przyrosty wydajności czynników produkcji [Dadush 2016]. W przypadku wystąpienia sekularnej stagnacji lub zagrożenia nią nie ma samokorygujących się mechanizmów powrotu do równowagi przy pełnym zatrudnieniu - bez odpowiedniej polityki ekonomicznej gospodarka może utknąć w pułapce niskiego wzrostu [Duprat 2015].

Większość dostępnej literatury na temat sekularnej stagnacji dotyczy Stanów Zjednoczonych (m.in. [Blecker 2016; Gordon 2012; 2014; Summers 2015; 2016]); tymczasem ryzyko trwałego spowolnienia wzrostu jest wyższe w krajach Unii Europejskiej (zwłaszcza strefy euro) niż w USA, ze względu na mniej korzystne warunki demograficzne, niższy przyrost wydajności, ciężar konsolidacji fiskalnej [Crafts 2014]. Czynnikom popytowym poświęcono wiele uwagi - szeroko dyskutowana jest polityka EBC oraz pakiety fiskalne, ukierunkowane na wzrost inwestycji publicznych, w miarę możliwości przy współpracy z sektorem prywatnym. Rzadziej natomiast analizowane są zagrożenia o strukturalnym charakterze, w szczególności kurczenie się zasobu siły roboczej, trwale wyższe stopy oszczędności prywatnych, które związane są ze starzeniem się społeczeństw naszego kontynentu, a także rozbieżności między popytem na pracę a kwalifikacjami pracowników oraz relatywnie niskie stopy aktywności zawodowej, zwłaszcza wśród młodzieży.

Ostatnie miesiące przyniosły poprawę wyników gospodarczych w niektórych krajach rozwiniętych, przede wszystkim w USA, co może być sygnałem zmiany koniunktury w całej gospodarce światowej; nie oznacza to jednak rozwiązania wszystkich problemów, z jakimi boryka się Europa. Celem niniejszego opracowania jest ustalenie, na ile realna jest groźba sekularnej stagnacji w krajach Unii Europejskiej, ze szczególnym uwzględnieniem strefy euro; potencjalne przyczyny trwałego spowolnienia wzrostu omówiono w części drugiej artykułu. Kolejny cel to zidentyfi- 
kowanie narzędzi w zakresie polityki ekonomicznej oraz reform instytucjonalnych, które sprzyjać będą odzyskaniu/utrzymaniu trwałego wzrostu pomimo poważnych zagrożeń strukturalnych - zostaną one omówione w części trzeciej. Część czwarta zawiera podsumowanie i wnioski.

\section{Przyczyny stagnacji w krajach rozwiniętych}

Sekularna stagnacja to „długoterminowa tendencja do chronicznie wolnego przeciętnego wzrostu, w przeciwieństwie do (lub w dodatku do) ostrej krótkookresowej recesji lub słabego ożywienia w cyklu koniunkturalnym" [Blecker 2016, s. 1]. W efekcie w dłuższym okresie utrzymuje się niski wzrost gospodarczy, wysokie bezrobocie i niska inflacja lub deflacja. Analiza stóp wzrostu w krajach UE oraz USA zdaje się wskazywać na jego wyraźne spowolnienie (rys. 1).

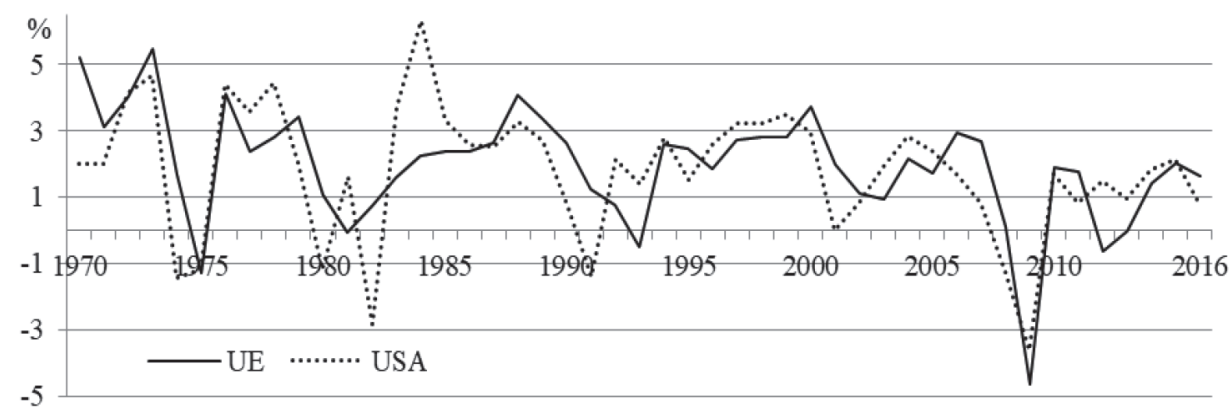

Rys. 1. Stopy wzrostu PKB per capita w USA i strefie euro, 1970-2016

Źródło: opracowanie własne na podstawie danych Banku Światowego (World Development Indicators).

W swym głośnym wystąpieniu z 1938 r. A. Hansen stwierdził, że główną przyczyną przedłużającej się recesji po Wielkim Kryzysie był brak bodźców do inwestycji wystarczająco dużych, by mogły zaabsorbować łączne oszczędności. Drugi ważny czynnik to wyczerpujące się możliwości ekspansji terytorialnej, którym współcześnie odpowiadają ograniczenia globalizacji. Po trzecie, Hansen założył koniec przełomowych odkryć naukowych oraz malejące korzyści z wykorzystania odkryć wcześniejszych; obecnie kwestia ta jest bardziej problematyczna․ Po czwar-

\footnotetext{
${ }^{1}$ Przegląd opinii na ten temat przedstawia Gordon [2014], tamże wykaz literatury. Gordon [2012] podkreśla, że fundamentalne wynalazki i zmiany organizacyjne (elektryczność, silnik spalinowy, kanalizacja, urbanizacja, powszechna edukacja) mogą zostać dokonane tylko raz, co ogranicza pole dla przyszłych odkryć o równie przełomowym charakterze - nie oznacza to oczywiście zakończenia postępu technicznego. Można jednak oczekiwać (a potwierdza to przebieg obecnej rewolucji cyfrowej, w której najwięcej udoskonaleń dotyczy narzędzi służących rozrywce, a nie produkcji materialnej), że przeciętne korzyści płynące z nowych odkryć będą mniejsze niż dawniej.
} 
te, innowacje kapitałooszczędne pozwalają osiągnąc te same możliwości produkcyjne przy niższych nakładach inwestycyjnych. I wreszcie starzenie się społeczeństw powoduje dezinwestycje (ubytek kapitału trwałego), zwłaszcza tam, gdzie istnieją odwrotne kredyty hipoteczne lub renty dożywotnie powiązane z własnością nieruchomości. W takiej sytuacji zawodzą tradycyjne metody stymulowania popytu (ulgi podatkowe, niskie stopy procentowe); rozwiązaniem są jedynie przemyślane inwestycje publiczne, w szczególności poprawiające warunki dla inwestycji prywatnych (nakłady na infrastrukturę, edukację itp.).

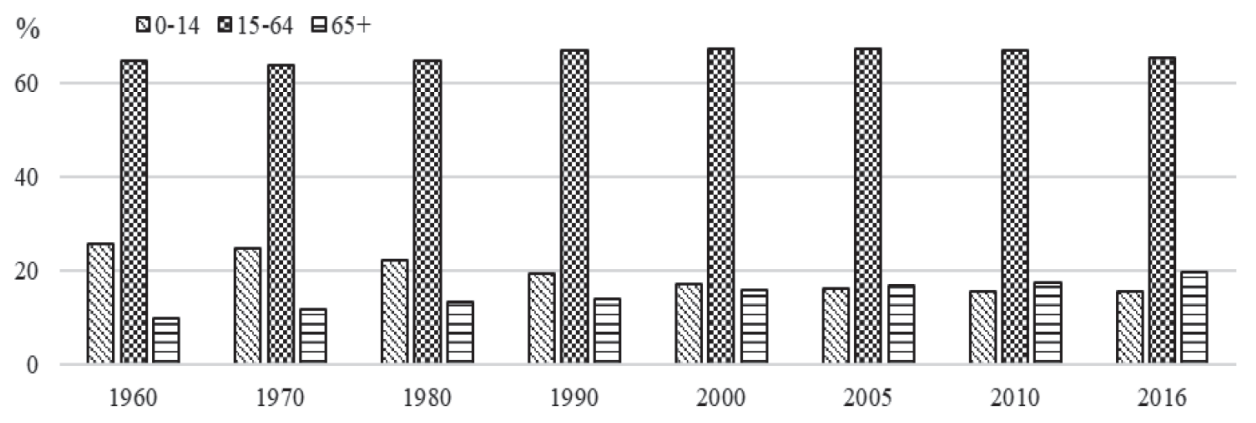

Rys. 2. Zmiana struktury wiekowej ludności UE, 1960-2016

Źródło: opracowanie własne na podstawie danych Banku Światowego (World Development Indicators).

Najczęściej analizowana potencjalna przyczyna sekularnej stagnacji, wolniejszy przyrost naturalny, na pierwszy rzut oka zdaje się zaprzeczać faktom: według szacunków ONZ liczba ludności świata wzrośnie z obecnych ok. 7,3 mld do 9,7 mld w 2050 r. Tymczasem według wielu ekspertów głównym zagrożeniem jest nie tyle zbyt duża liczba ludności, co niedostatek młodych pracowników; największy udział w przyroście ludności mają osoby powyżej 50. roku życia, natomiast najszybciej rosnąca grupa to osoby, które przekroczyły lat 80 . Niemal połowa ludności świata żyje w jednym z 83 krajów (m.in. Brazylia, Chiny, Niemcy, Rosja, Stany Zjednoczone i Polska), gdzie współczynnik dzietności kobiet kształtuje się poniżej wymaganego dla zastępowalności pokoleń 2,1 [Sharma 2016, s. 20]. W krajach UE liczba ludności w wieku produkcyjnym zaczęła spadać już od 2005 r. (por. rys. 2); według szacunków zasób siły roboczej (osoby w wieku 15-64 lat) zmniejszy się w całej Europie Zachodniej (UE + Norwegia i Szwajcaria) o $14 \mathrm{mln}$ do 2030 r. i aż o $42 \mathrm{mln}$ do 2050 r. [Labaye i in. 2015, s. 1].

Zmiana struktury wiekowej ludności wpływa na efektywną podaż pracy poprzez dwa kanały: zmianę stopy aktywności zawodowej oraz zmianę struktury kwalifikacji (i produktywności) wśród aktywnych zawodowo (poziom wykształcenia, doświadczenie zawodowe, stan zdrowia). Na podstawie danych dla USA (1980-2010) Maestas i wsp. [2016, s. 2] stwierdzają, że wzrost odsetka osób 60+ w populacji 
o $10 \%$ obniża tempo wzrostu PKB per capita o 5,5\%, przy czym dwie trzecie tego efektu wynika z wolniejszego przyrostu wydajności pracy, reszta - z niższego wzrostu zasobu siły roboczej. Zależność między przeciętnym wiekiem pracownika a wydajnością pracy ma kształt odwróconej litery $\mathrm{U}$ - przyrosty wydajności rosną wraz ze wzrostem udziału pracowników w wieku 40-49 lat i spadają, kiedy zwiększa się udział starszych pracowników [Feyrer 2008]. Działanie tego mechanizmu nie jest jednak bezsporne; gdyby hipoteza ta była słuszna, największe problemy gospodarcze dotyczyłyby krajów, w których najszybciej postępuje starzenie się ludności. Acemoglu i Restrepo [2017] analizują okres 1990-2010, w którym skutki zmian demograficznych stały się już odczuwalne, nie znajdując żadnej zależności: ,nawet przy uwzględnieniu początkowego PKB per capita, początkowej struktury demograficznej oraz zróżnicowanych trendów w poszczególnych regionach, nie ma dowodów na negatywną korelację między starzeniem się a PKB per capita; przeciwnie, zależność jest istotnie dodatnia dla wielu specyfikacji” (s. 2). Acemoglu i Restrepo jako wyjaśnienie proponują pojawienie się technologii pracooszczędnych, dzięki którym ubytek siły roboczej wyrównywany jest poprzez mechanizację i automatyzację produkcji. Podobnego zdania jest Sharma [2016, s. 24], według którego „możliwe jest, że roboty pojawią się w samą porę, aby złagodzić groźne skutki depopulacji”’.

Analizując sytuację w Stanach Zjednoczonych, Glaeser [2014] zwraca uwagę, że liczba dorosłych pozostających bez pracy rośnie już od kilku dekad - określa to zjawisko jako „sekularny brak zatrudnienia” (secular joblessness). W opinii Glaesera sytuacja taka nie zmieni się nawet w razie trwałej poprawy koniunktury - konieczne są reformy strukturalne: „Dysfunkcja rynku pracy jest realna i poważna, i nie wydaje się prawdopodobne, by rozwiązał ją jakikolwiek oczywisty trend ekonomiczny". Co istotne, mniej więcej od lat 70. stopa braku pracy (suma stopy bezrobocia i nieaktywności zawodowej) nie powraca do poprzedniego poziomu po każdej recesji, lecz pozostaje nieco wyższa niż wcześniej, pomimo spadku bezrobocia. Tym większe zagrożenie dotyczy silniej regulowanych rynków pracy w UE, które nawet w czasie dobrej koniunktury cechują się niższą aktywnością zawodową i wyższym bezrobociem.

Wydaje się, że w długiej perspektywie szczególnie groźny dla gospodarek UE może być wysoki odsetek osób młodych pozostających poza systemem edukacji i rynkiem pracy (Not in Employment, Education or Training, NEET); w krajach najsilniej dotkniętych recesją młodzi ludzie pozbawieni jakiegokolwiek zajęcia stanowią nawet kilkanaście procent grupy wiekowej 15-24 lata (rys. 3). Rosnąca liczba

\footnotetext{
${ }^{2}$ Szybka automatyzacja w wielu branżach produkcji rodzi obawy, że maszyny i nowe technologie w coraz większym stopniu zastępować będą pracowników, zwłaszcza o niskich kwalifikacjach; proces ten Acemoglu i Restrepo [2015] nazywają wprost „wyścigiem między człowiekiem a maszyną”. Jego przejawem jest m.in. malejący udział pracy w dochodzie narodowym, jaki w ostatnich dekadach odnotowano w wielu krajach, zwłaszcza rozwiniętych. Z drugiej strony - nowe technologie tworzą nowe zadania (stanowiska), które choć początkowo wymagają wysokich kwalifikacji, z czasem stają się ustandaryzowane i mogą być wykonywane przez niewykwalifikowanych pracowników.
} 
NEET świadczy o problemach w systemie edukacji/kształcenia, być może również o niewydolności systemów pośrednictwa pracy i wsparcia zawodowego.

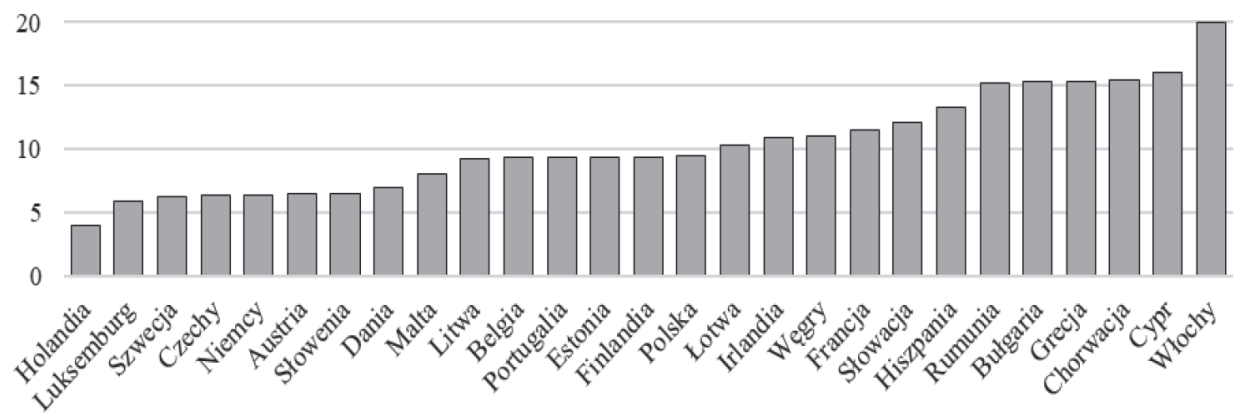

Rys. 3. NEET w krajach UE (\% młodzieży w wieku 15-24 lat), 2015 r.

Źródło: opracowanie własne na podstawie danych MOP.

Jedną z pozostałości po globalnym kryzysie finansowym jest nasilenie niepewności w obrocie gospodarczym, zwłaszcza na rynkach finansowych, ale również na rynku pracy, gdzie upowszechniają się np. ,śmieciowe” formy zatrudnienia. Niepewność nie sprzyja wzrostowi, gdyż zniechęca do inwestowania, szczególnie w duże projekty, rozłożone w czasie i/lub przynoszące zyski dopiero w dłuższym okresie (obniża elastyczność inwestycji względem stopy procentowej [OECD 2015]); skłania gospodarstwa domowe (a w pewnych okolicznościach również podmioty publiczne) do gromadzenia oszczędności; ogranicza rozwój pośrednictwa finansowego, ponieważ właściciele kapitału preferują bezpieczne aktywa. W rezultacie mimo dużej podaży płynnych środków rośnie klin między zwrotem z oszczędności a kosztem kredytu.

Koo [2013] zwraca uwagę na konieczność poprawy bilansów nadmiernie zadłużonych podmiotów prywatnych, zarówno firm, jak i konsumentów, co skłania do redukcji wydatków (recesja bilansowa, balance sheet recession). Delewarowanie oznacza, że podmioty prywatne nie są skłonne do zaciągania nowych pożyczek, pomimo utrzymywania przez banki centralne niskich stóp procentowych. Przedsiębiorstwa są bardziej zainteresowane poprawą bilansów niż rozbudową potencjału produkcyjnego; gospodarstwa domowe spłacają zadłużenie i gromadzą oszczędności. Nie ma też wielu potencjalnych wierzycieli ze względu na wysokie ryzyko - banki również dążą do uzdrowienia własnych bilansów, wybierając bezpieczne aktywa $^{3}$. Osłabia to znacząco skuteczność tradycyjnej polityki pieniężnej i tłumaczy

${ }^{3} \mathrm{~W}$ krajach dotkniętych deflacją proces delewarowania jest jeszcze trudniejszy, ponieważ spadek cen zwiększa realny ciężar zadłużenia, co skłania do obniżenia wydatków, pogłębiając spadek cen i domykając błędne koło. 
stagnację inwestycji i konsumpcji ${ }^{4}$. Także wysoki dług publiczny przyczynia się do spadku popytu, jeśli zmusza rząd do ograniczenia wydatków i/lub wymusza podwyżkę podatków, zmniejszając popyt prywatny.

Hansen [1939] podkreślał, że niskie stopy przyrostu naturalnego w gospodarkach rozwiniętych powodują spadek inwestycji. Mniejszy zasób pracy w stosunku do kapitału oznacza malejące krańcowe stopy zwrotu z kapitału, prowadząc do spadku opłacalności inwestycji i zmniejszenia nakładów inwestycyjnych. Ponadto potrzeba przeznaczenia większej części zasobów na konsumpcję osób starszych pozostawia mniejsze zasoby inwestycyjne. Summers [2015, 2016] uzupełnia listę przyczyn niższych inwestycji o spadek relatywnych cen dóbr kapitałowych, w wyniku czego dany projekt inwestycyjny realizowany jest przy mniejszej absorpcji oszczędności5; trudniejszy dostęp do kredytu, w tym silniejsze regulacje dotyczące zdolności kredytowej; usługi cyfrowe zastępujące tradycyjne formy świadczenia usług; szybki postęp techniczny, powodujący gwałtowną amortyzację istniejących technologii. Niedobór inwestycji oznacza nie tylko niższą produkcję obecnie, ale również mniejsze możliwości produkcyjne w przyszłości. W tym zakresie szczególnie niekorzystne mogą okazać się mniejsze nakłady na infrastrukturę i kapitał niezbędny do świadczenia usług publicznych (szkoły, szpitale, sieci wodociągowe i telekomunikacyjne itp.). W Europie (UE plus Szwajcaria i Norwegia) łączne inwestycje (publiczne i prywatne) spadły o 261 mld euro rocznie w okresie 2008-2015, z czego inwestycje przedsiębiorstw spadły o 109 mld euro, inwestycyjne wydatki konsumentów o 118 mld euro, inwestycje publiczne o 34 mld euro [Manyika i in. 2016, s. 1 i nast.].

Drugą stroną niedoboru popytu jest wzrost oszczędności, który wynika z kilku powodów [Summers 2016]: wyższego udziału dochodu przypadającego najbogatszym; niepewności dotyczącej czasu trwania emerytur i dostępności świadczeń; pogorszenia się zdolności kredytowej, zwłaszcza w przypadku kredytów hipotecznych; większej skłonności do gromadzenia rezerw przez podmioty publiczne, w tym banki centralne. Choć decyzje konsumentów, inwestorów i rządów o gromadzeniu oszczędności są indywidualnie racjonalne, razem wzięte powodują osłabienie popytu i wolniejszy powrót do tempa wzrostu sprzed kryzysu [Labaye i in. 2015]. Co ważne, wolniejszy wzrost dochodu i wyższe oszczędności napędzają się nawzajem: niższy wzrost oznacza dla gospodarstw domowych mniejsze zarobki w cyklu życia ${ }^{6}$, a zatem konsumenci będą musieli oszczędzić większą część dochodu, aby przetrwać

${ }^{4}$ W 2008 r. w strefie euro sektor przedsiębiorstw zaciągał zadłużenie netto w wysokości 11,8\% PKB, natomiast w 2014 r. gromadził oszczędności netto w wysokości 3,4\% PKB. W tym samym czasie oszczędności konsumentów wzrosły z 7,9 do 12,5\% PKB [Duprat 2015, s. 10]. Mówiąc inaczej, między 2008 a 2014 rokiem popyt prywatny w strefie euro zmniejszył się łącznie niemal o 20\% PKB.

${ }^{5}$ Ceny dóbr inwestycyjnych w relacji do ogólnego poziomu cen spadły o ok. $30 \%$ od lat 80 . XX wieku [Manyika i in. 2016, s. 4].

${ }^{6}$ Wzrost dochodu niższy o zaledwie 0,5 p.proc. w ciągu 40 lat życia zawodowego oznacza w chwili przejścia na emeryturę dochód niższy o 22\% [Dadush 2016, s. 10]. 
okres emerytalny, tym bardziej że średnia długość życia wzrośnie. Trwale wolniejszy wzrost sprawi również, że rządy będą musiały podnieść podatki w celu sfinansowania wydatków emerytalnych i na opiekę zdrowotną - równoważność Ricardo sugeruje, że obecne oszczędności na poczet przyszłych podatków wzrosną.

Znaczne nierówności dochodu mogą ograniczać wzrost poprzez co najmniej trzy mechanizmy?: po pierwsze, spada popyt konsumpcyjny, ponieważ bogaci cechują się niższą skłonnością do konsumpcji niż ubożsi; po drugie, mniejsza równość szans utrudnia biedniejszym realizację ich ekonomicznego i społecznego potencjału; po trzecie, nasilają się konflikty społeczne, podziały polityczne, rośnie przestępczość. Wyrównywanie się cen czynników produkcji, będące wynikiem procesów globalizacji oraz upowszechniania się nowych form świadczenia pracy, jest w krajach rozwiniętych niekorzystne dla pracowników o niskich kwalifikacjach (wzrost rozpiętości wynagrodzeń), poszerzają się także dysproporcje dochodu pozapłacowego.

Niezależnie od osłabienia popytu prywatnego, dodatkowym problemem utrudniającym wyjście z recesji jest nieskuteczność tradycyjnej polityki popytowej. O kwestiach związanych z zadłużeniem publicznym była już mowa; w takich przypadkach odpowiedzialność za pobudzenie gospodarki przejmowały zwykle władze monetarne, co jednak w obecnych warunkach jest trudne. Jak wskazuje Summers [2015], zero jako dolna granica nominalnych stóp procentowych (Zero Lower Bound, ZLB) stanowi naturalną niedoskonałość rynku pieniężnego, która może odpowiadać za przedłużające się spadki dochodu. Dolna granica stopy polityki pieniężnej wyznacza $\mathrm{z}$ kolei granice dla innych stóp procentowych, które uwzględniają premię za czas i ryzyko kredytowe. „Skoro popyt jest funkcją realnych stóp procentowych, a te z kolei zależą od oczekiwanej inflacji lub deflacji, nie ma gwarancji, że realna stopa będzie wystarczająco niska dla pełnego zatrudnienia" [Summers 2015, s. 61]. Mówiąc inaczej: jeśli inwestycje zależą ujemnie od realnej stopy procentowej, zaś oszczędności - dodatnio, może się zdarzyć, że stopa dająca równowagę przy pełnym zatrudnieniu będzie mieć znak ujemny; wówczas gospodarka przeniesie się na niższy poziom produkcji, który może utrzymać się w długim okresie [IMF 2014]. Sytuację pogorszyć może deflacja, która z jednej strony podnosi realne stopy procentowe, z drugiej - powoduje redystrybucję zasobów od dłużników (wysoka skłonność do konsumpcji) do kredytodawców (niska skłonność do konsumpcji). Ponadto niskie nominalne i realne stopy procentowe mogą zagrażać stabilności finansowej, ograniczając zyski i odporność instytucji finansowych, skłaniając właścicieli kapitału do ponoszenia nadmiernego ryzyka (w poszukiwaniu wyższych stóp zwrotu), a tym samym zwiększając prawdopodobieństwo baniek spekulacyjnych [Ferrero i in. 2017]. Ponadto, jak słusznie podkreślają Eggertsson i wsp. [2017, s. 43], gdyby hipoteza new normal okazała się błędna, wówczas popytowe narzędzia walki z przedłużającą się stagnacją (wyższa inflacja, wzrost deficytów budżetowych, hojniejsze

${ }^{7}$ Szerzej na ten temat [Sordyl 2017], tamże wykaz literatury. 
transfery socjalne) mogą okazać się „tak bezproduktywne i kosztowne, jak sugeruje tradycyjna teoria ekonomii".

\section{Narzędzia przeciwdziałania trwałemu spowolnieniu wzrostu}

Szacunki wskazują, że kraje strefy euro mogą wrócić do ścieżki wzrostu sprzed kryzysu (skorygowanej o nadmierną akumulację kapitału w czasie boomu przed globalnym kryzysem finansowym), przy spełnieniu trzech warunków [Pichelmann 2015]: po pierwsze, wzrost bezrobocia nie wywoła silnego efektu histerezy; po drugie, gospodarka nadrobi spadek wydajności czynników produkcji (Total Factor Productivity, TFP); po trzecie, przedsiębiorstwa wykorzystają niskie koszty kredytu do zwiększenia inwestycji; powinno to dać średnie stopy wzrostu na poziomie $1,4 \%$ w najbliższej dekadzie. Jednocześnie należy wziąć pod uwagę istotne formy ryzyka: spadek zatrudnienia może okazać się trwały, podobnie jak niekorzystny trend TFP (spadek wydajności obserwowano już w ciągu trzech dziesięcioleci przed kryzysem); nie ma pewności, czy mechanizmy dostosowania cen i płac okażą się wystarczająco skuteczne, aby przywrócić równowagę przy pełnym zatrudnieniu; unikanie ryzyka i niskie zaufanie może przyczyniać się do niższego popytu; ekspansja fiskalna może nasilić ryzyko, a tym samym podnieść koszty obsługi zadłużenia.

Jak zaznacza Duprat [2015, s. 7], Unia Europejska „wydaje się kiepsko przystosowana do sprostania wyzwaniu sekularnej stagnacji ze względów politycznych i instytucjonalnych". Dla przyszłości UE zasadnicze znaczenie mają dwa czynniki strukturalne: starzenie się społeczeństw kontynentu oraz mogący trwać nawet kilka dziesięcioleci proces delewarowania po globalnym kryzysie finansowym [Gimdal, Karakas 2016] ${ }^{8}$. Narzędzia przezwyciężania stagnacji mogą mieć formę odpowiedniej polityki ekonomicznej i/lub zmian instytucjonalnych na poziomie krajowym oraz ponadnarodowym. Szczególną uwagę należy zwrócić na uzupełnienie niedoborów popytu w krótkim i średnim okresie (ekspansywna polityka fiskalna, redystrybucja dochodu, pobudzanie inwestycji prywatnych) oraz zwiększanie zasobów produkcyjnych w średnim i długim okresie (podniesienie stóp urodzeń, aktywizacja zawodowa grup społecznych cechujących się niższym udziałem w rynku pracy, kontrolowana imigracja, zachęty do innowacji i poprawy wydajności).

Przezwyciężenie pułapki płynności wymaga przekonania społeczeństwa, że bank centralny jest skłonny prowadzić luźną politykę pieniężną nawet przy dodatniej inflacji i nawet wówczas, gdy recesja już się zakończy; mówiąc inaczej, „bank centralny musi złożyć wiarygodną obietnicę bycia nieodpowiedzialnym" [Krugman 2014, s. 65]. Osiągnięcie wyższej inflacji wymaga wyższych oczekiwań inflacyjnych, które z kolei wymagają wiary w ożywienie gospodarcze - jeśli ożywienie nie wystąpi, rzeczywista inflacja ustali się poniżej oczekiwanej, co osłabi wiarygodność

\footnotetext{
${ }^{8}$ Osobny problem to czynniki o charakterze politycznym, zagrażające stabilności instytucji Unii kwestie te pozostają jednak poza zakresem niniejszego opracowania.
} 
i obniży oczekiwania; Krugman nazywa to zjawisko „pułapką lękliwości” (timidity trap). EBC ma w tym kontekście specyficzny problem: jego dobra renoma w walce $\mathrm{z}$ inflacją powoduje, że zapowiedzi wyższej inflacji nie są mocno wiarygodne.

Jedną z możliwości absorpcji nadwyżki oszczędności prywatnych jest zwiększenie wydatków rządowych, zwłaszcza nakładów na inwestycje publiczne, edukację, badania i rozwój itp. ${ }^{9}$ DeLong i Summers [2012] sugerują, że w warunkach stagnacji ekspansja fiskalna może wręcz poprawić stan budżetu, ze względu na silniejsze niż zwykle działanie mnożnika wydatków publicznych. Manyika i wsp. [2016] proponują nowe podejście do rachunkowości długu publicznego, w szczególności uznanie inwestycji publicznych za aktywa, co zwiększyłoby swobodę władz fiskalnych. Ważnym elementem zmian $\mathrm{w}$ finansach publicznych są działania poprawiające dystrybucję dochodu [Pichelmann 2015]:

- reforma systemu ochrony socjalnej: transfery socjalne (również rzeczowe) zapewniają bezpieczeństwo najbardziej zagrożonym grupom społecznym; duże znaczenie ma precyzyjna konstrukcja programów pomocy i wskazanie grupy docelowej;

- reformy systemów podatkowych pod kątem krajowych nierówności dochodu (zmiana rozkładu ciężaru podatkowego od dochodu ku aktywom), uwzględniające fakt, że przepływy czynników produkcji między granicami ograniczają skuteczność opodatkowania redystrybucyjnego; unikanie podatków i erozja bazy podatkowej wymaga skoordynowania działań między krajami członkowskimi.

Aby zmiany w polityce ekonomicznej miały oczekiwane skutki, muszą towarzyszyć im dostosowania strukturalne. Jeśli np. banki centralne będą utrzymywać luźną politykę pieniężną, brak odpowiednich zmian regulacyjnych na rynkach finansowych doprowadzi jedynie do powstawania baniek spekulacyjnych zamiast do wzrostu inwestycji rzeczowych [OECD 2015]. Reformy strukturalne powinny zapewnić przewidywalność i wysoką jakość regulacji, stworzyć źródła finansowania dla sektora prywatnego, zwłaszcza małych i średnich przedsiębiorstw, usunąć bariery regulacyjne w ramach wspólnego rynku. Pichelmann [2015] proponuje bardziej szczegółowe rozwiązania:

- na poziomie UE przydatne może być wdrożenie mechanizmów monitorujących absorpcję wstrząsów przez gospodarki krajowe, a dzięki temu wzmacnianie stabilizacji oraz propagowanie dobrych wzorców i wskazywanie potencjalnych obszarów reform; w razie nieprzewidzianych okoliczności zaprojektowanie mechanizmów szybkiego reagowania;

\footnotetext{
${ }^{9}$ Komisja Europejska uruchomiła w 2015 r. specjalny fundusz inwestycyjny (European Fund for Strategic Investment) o budżecie nie niższym niż 315 mld euro, który w 2017 r. zwiększono do 500 mld euro do 2020 r. Celem projektu jest pobudzenie inwestycji i zwiększenie konkurencyjności gospodarek UE oraz stworzenie nowych miejsc pracy. W 2017 r. łączna kwota inwestycji powiązanych z EFIS wyniosła niemal 260 mld euro, a ze wsparcia finansowego skorzystało ponad pół miliona małych i średnich przedsiębiorstw, http://www.eib.org/infocentre/publications/all/european-fund-for-strategic-investments-in-2017.htm (25.05.2018).
} 
- nakłady na kapitał ludzki: zapewnienie dostępu do wysokiej jakości edukacji, wspieranie kształcenia pracowników; rozwój edukacji przedszkolnej;

- inkluzywna polityka mieszkaniowa.

Manyika i wsp. [2016] uzupełniają tę listę o nowe podejście do regulacji o charakterze ochronnym; chodzi tu z jednej strony o rynki pracy i prawa pracowników, $\mathrm{z}$ drugiej - o ochronę środowiska naturalnego (zwłaszcza jego zasobów nieodnawialnych) i przeciwdziałanie zmianom klimatu. W zakresie rynku pracy jako szczególnie ważne Labaye i wsp. [2015] wymieniają:

- zwiększanie zatrudnienia i szans kariery zawodowej (more and better jobs), zwłaszcza dla grup najbardziej wrażliwych;

- umożliwienie młodym pracownikom przejścia z systemu edukacji do zatrudnienia (lepsza dostępność informacji o dostępnych/powstających stanowiskach, programy praktyk i staży, właściwe przygotowanie nauczycieli, ocena szkół i jakości nauczania) ${ }^{10}$;

- zwiększenie stóp aktywności kobiet i osób starszych ${ }^{11}$,

- imigrację sprzyjającą wzrostowi,

- walkę z segmentacją rynków pracy,

- elastyczność rynków pracy, zwłaszcza w zakresie mobilności pracowników (geograficznej i zawodowej) $^{12}$.

Eksperci OECD [2015, s. 9] podkreślają rolę przedsiębiorczości, zwłaszcza tej na mniejszą skalę: „Małe i średnie firmy oraz przedsiębiorcy są kluczowymi siłami napędowymi innowacji i wzrostu wydajności, przekształcając kreatywność i aktywa intelektualne $\mathrm{w}$ wartość ekonomiczną, przynosząc na rynek nowe pomysły i zastępując mniej produktywne rozwiązania". Odpowiadają również za powstawanie bardzo wielu miejsc pracy (średnia dla OECD to ok. $70 \%$ zatrudnienia ogółem). Duże znaczenie mają tu reformy ograniczające niepewność związaną z otoczeniem regulacyjnym, złożonością i niespójnością przepisów, ułatwiające egzekwowanie umów, ograniczające ciężary podatkowe, zwłaszcza w razie trudności ekonomicznych.

\footnotetext{
${ }^{10}$ Krokiem we właściwym kierunku jest zainicjowany w 2013 r. program „Gwarancja dla młodzieży” (Youth Guarantee), który przewiduje zapewnienie młodym osobom (do 25. roku życia) dobrej oferty pracy, praktyki, szkolenia zawodowego lub dalszego kształcenia, dostosowanej do indywidualnych zdolności i doświadczenia, w ciągu czterech miesięcy od zakończenia edukacji lub stania się bezrobotnym [Escudero, López Mourelo 2015]. Programy w poszczególnych krajach są zróżnicowane, obejmują jednak wspólne elementy: kształcenie ogólne i zawodowe sprzyjające zatrudnieniu, łącznie z umożliwieniem powrotu do systemu edukacji powszechnej; usługi pośrednictwa pracy, indywidualne planowanie kariery zawodowej; narzędzia aktywnej polityki rynku pracy (subsydiowanie zatrudnienia, programy praktyk zawodowych, ułatwienia w podejmowaniu działalności gospodarczej).

${ }^{11} \mathrm{~W}$ przypadku tej grupy duże znaczenie dla aktywności zawodowej może mieć dostępność różnych form opieki nad najmłodszymi i najstarszymi członkami rodzin, podobnie jak istnienie elastycznych form świadczenia pracy (telepraca, praca w niepełnym wymiarze itp.). Obecne systemy podatkowe i socjalne często de facto penalizują podjęcie pracy przez drugą osobę w rodzinie [OECD 2015].

${ }^{12}$ Postulat elastyczności należy jednak łączyć z zapewnieniem silniejszej ochrony pracownikom zmieniającym status na rynku pracy (flexicurity); jest to szczególnie ważne w warunkach globalizacji i nasilonej konkurencji [Sordyl 2014].
} 


\section{Podsumowanie}

Poprawa koniunktury w ostatnich kwartałach stwarza nadzieję odzyskania przez kraje rozwinięte stabilnego wzrostu; dali temu wyraz eksperci MFW [IMF 2018], którzy w aneksie do ostatniego raportu World Economic Outlook mówią o ,jaśniejszych perspektywach" i „optymistycznych rynkach”. Z drugiej strony - nawet jeśli hipoteza sekularnej stagnacji okazałaby się niesłuszna w swej mocnej formie, strukturalne zagrożenia dla wzrostu są faktem, a przeciwdziałanie im wymaga współpracy krajów członkowskich. Konieczne działania obejmują nadzór mikro- i makroostrożnościowy, unikanie zagrożeń dla stabilności finansowej, rezygnację z protekcjonizmu. Wyrównaniu nierównowagi między oszczędnościami a inwestycjami służy integracja handlowa, BIZ, swobodne przepływy kapitału [Pichelmann 2015]. Reformy po stronie podażowej, zwłaszcza poprawa efektywności rynków czynników produkcji, mogą podnieść naturalną stopę procentową, rozwiązując kwestię zero lower bound.

Pilnej reakcji wymagają problemy rynku pracy: wolniejszy przyrost lub bezwzględny spadek zasobu siły roboczej, wyższy udział starszych pracowników, dysproporcje dochodu, bariery utrudniające wejście na rynek młodym pracownikom i mniejszościom. Ponadto w globalnej i dynamicznej gospodarce konieczne jest z jednej strony przygotowanie pracowników do częstszych niż dawniej zmian statusu zawodowego, z drugiej - zapewnienie im ochrony przed skutkami wstrząsów na poziomie mikro- i makroekonomicznym. Nie da się też uniknąć dyskusji dotyczącej stanu środowiska naturalnego i wyczerpujących się zasobów. Względy te powodują, że być może należy liczyć się z trwale niższymi stopami wzrostu gospodarczego w krajach rozwiniętych.

\section{Literatura}

Acemoglu D., Restrepo P., 2015, The Race Between Man and Machine: Implications of Technology for Growth, Factor Shares and Employment, https://bfi.uchicago.edu/sites/default/files/research/ Man_Vs_Machine_October_16_2015.pdf (31.12.2017).

Acemoglu D., Restrepo P., 2017, Secular Stagnation? The Effect of Aging on Economic Growth in the Age of Automation, https://economics.mit.edu/files/12536 (28.12.2017).

Blecker R.A., 2016, The US economy since the crisis: slow recovery and secular stagnation, http://fs2. american.edu/blecker/www/research/Blecker-stagnation-rev-Mar2016.pdf (17.12.2017).

Crafts N., 2014, Secular stagnation: US hypochondria, European disease?, [w:] Secular Stagnation: Facts, Causes, Cures, eds. C. Teulings, R. Baldwin, CEPR Press, London.

Dadush U., 2016, Should Developing Countries Fear Secular Stagnation?, OCP Policy Center, Policy Paper PP-16/10, July.

DeLong J.B., Summers L., 2012, Fiscal policy in a depressed economy, Brooking Papers on Economic Activity, vol. 43, no. 1, s. 233-297.

Duprat M.H., 2015, Euro zone: In the grip of 'Secular Stagnation'?, ECONOTE, no. 28, March.

Eggertsson G.B., Mehrotra N.R., Robbins J.A., 2017, A model of secular stagnation: Theory and quantitative evaluation, NBER Working Paper, no. 23093, http://www.nber.org/papers/w23093 (15.02.2018). 
Escudero V., López Mourelo E., 2015, The Youth Guarantee programme in Europe: Features, implementation and challenges, Research Department Working Paper, no. 4, International Labour Office, August.

Ferrero G., Gross M., Neri S., 2017, On secular stagnation and low interest rates: demography matters, Working Paper, no. 2088, European Central Bank, July.

Feyrer J., 2008, Aggregate evidence on the link between age structure and productivity, Population and Development Review, vol. 34, s. 78-99.

Gimdal G., Karakas C., 2016, Secular stagnation and the euro area, European Parliamentary Research Service, February.

Glaeser E.L., 2014, Secular joblessness, [w:] Secular Stagnation: Facts, Causes, Cures, eds. C. Teulings, R. Baldwin, CEPR Press, London.

Gordon R.J., 2012, Is U.S. Economic Growth Over?, Faltering Innovation Confronts the Six Headwinds, NBER Working Paper, no. 18315, August.

Gordon R., 2014, US economic growth is over: The short run meets the long run, [w:] Growth, Convergence and Income Distribution: The Road from the Brisbane G-20 Summit, http://www.guntramwolff.net/wp-content/uploads/2015/05/TT20-Nov-7-FINAL-Web-v2.pdf (14.12.2017).

Hansen A.H., 1939, Economic progress and declining population growth, American Economic Review, vol. 29 , no. 1 , s. $1-15$.

IMF, 2014, Perspectives on global interest rates, IMF World Economic Outlook, Chapter 3, April.

IMF, 2018, World Economic Outlook Update: Brighter Prospects, Optimistic Markets, Challenges Ahead, https://www.imf.org/en/Publications/WEO/Issues/2018/01/11/world-economic-outlook-update-january-2018 (15.05.2018).

Koo R., 2013, Balance sheet recession as the 'other half' of macroeconomics, European Journal of Economics and Economic Policies, vol. 10, no. 2, s. 136-157.

Krugman P., 2014, Four observations on secular stagnation, [w:] Secular Stagnation: Facts, Causes, Cures, eds. C. Teulings, R. Baldwin, CEPR Press, London.

Labaye E., Smit S., Windhagen E., Dobbs R., Mischke J., Stone M., 2015, A Window of Opportunity for Europe, McKinsey Global Institute, June.

Maestas N., Mullen K.J., Powell D., 2016, The effect of population aging on economic growth, the labor force and productivity, NBER Working Paper, no. 22452, July.

Manyika J., Labaye E., Bughin J., Mischke J., Ramaswamy S., 2016, Secular Stagnation and Low Investment: Breaking the Vicious Cycle, McKinsey Global Institute Discussion Paper, April.

OECD, 2015, Escaping the Stagnation Trap: Policy Options for the Euro Area and Japan, https:// www.oecd.org/japan/escaping-the-stagnation-trap-policy-options-for-the-euro-area-and-japan.pdf (15.12.2017).

Pichelmann K., 2015, When 'Secular Stagnation'meets Piketty's capitalism in the $21^{\text {st }}$ century. Growth and inequality trends in Europe reconsidered, European Commission Economic Papers 551, July.

Sharma R., 2016, The Demographics of Stagnation. Why People Matter for Economic Growth, Foreign Affairs, no. 2, s. 18-24.

Sordyl M. , 2014, „Przyzwoite zatrudnienie” jako narzędzie antykryzysowe i szansa na zrównoważony wzrost, Zeszyty Naukowe Uniwersytetu Szczecińskiego. Studia i Prace Wydziału Nauk Ekonomicznych i Zarządzania, nr 35, t. 2, s. 209-237.

Sordyl M., 2017, Nierówności dochodu jako źródło podatności na zjawiska kryzysowe, [w:] Otwartość gospodarki a podatność na kryzysy w krajach na średnim poziomie rozwoju, red. M.A. Dąbrowski, A. Wojtyna, Wydawnictwo Naukowe PWN, Warszawa, s. 87-115.

Summers L.H., 2015, Demand side secular stagnation, American Economic Review, no. 5, s. 60-65.

Summers L.H., 2016, The age of secular stagnation. What it is and what to do about it, Foreign Affairs, no. 2 , s. $2-9$. 